\title{
LETTER
}

\section{Pericyte alteration sheds light on micro-vasculopathy in COVID-19 infection}

\author{
Nathalie Cardot-Leccia ${ }^{1}$, Thomas Hubiche ${ }^{2}$, Jean Dellamonica ${ }^{3}$, Fanny Burel-Vandenbos ${ }^{1}$ \\ and Thierry Passeron ${ }^{2,4^{*}}$ (1)
}

(c) 2020 Springer-Verlag GmbH Germany, part of Springer Nature

\section{Dear Editor,}

Understanding the mechanisms involved in SARS-CoV-2 infection is crucial to provide more efficient therapeutic approaches. Here, we report the histological patterns of skin and lung post-mortem analysis in patients hospitalized in intensive care unit that revealed a micro-vasculopathy secondary to pericyte alteration.

After family consent, we performed in-depth histological analysis, with a special focus on micro-vascularization, of post-mortem biopsies from COVID-19 positive patients hospitalized in intensive care unit. (Lung biopsies were taken from 2 patients, and skin biopsies from 4 patients.) The normal lung tissue used as control was from a 16-year-old patient cured for pneumothorax. Detailed methods are available in Supplementary Appendix.

As previously reported, we observed in the lung, patterns of diffuse alveolar damage (DAD) including exudative and proliferative changes. Interestingly, walls of venules and alveolar capillaries were thickened as compared to normal pulmonary vessels (Supplementary Fig. 1a, b, c). We did not observe any thrombi, and CD34 immunostaining showed no alteration of endothelial cells of those venules and capillaries (Supplementary Fig. 1d). At the contrary, pericytes were dramatically decreased in alveolar capillaries in COVID + lung, while they were abundant in normal parenchyma (Fig. 1a, b). Cleaved caspase 3 immunostaining revealed apoptosis of pericytes (Fig. 1c). The thickening of venules and capillaries and the loss of pericytes were observed not only in DAD

\footnotetext{
*Correspondence: passeron@unice.fr

${ }^{2}$ Department of Dermatology, Université Côte D’Azur. CHU Nice, Nice, France

Full author information is available at the end of the article

Nathalie Cardot-Leccia and Thomas Hubiche equal contribution.
}

territories, but also in non-inflammatory areas. Biopsies of apparent normal skin of the same two patients and two additional ones also showed a mild thickening of smallsized vessel wall in superficial dermis without inflammation (Supplementary Fig. 1e). In the skin, we did not observe a pericyte loss, but a mild hyperplasia of pericytes was noted (Supplementary Fig. 1f, g).

There are increasing data supporting a vascular involvement in COVID-19 patients. MRI performed in patients with neurologic signs revealed perfusion abnormalities in $100 \%$ of cases [1]. Dual-energy CT performed in COVID-19 pneumonia showed profound vascular and perfusion abnormalities without pulmonary emboli [2]. So far, studies emphasized thrombotic events or searched for endothelial cell alteration [3]. The lack of thrombi in our samples might be explained by the curative anticoagulation that our patients received. Sprouting and intussusceptive angiogenesis along with disruption of intercellular junctions, cell swelling, and a loss of contact with the basal membrane are the hallmarks of COVID19-infected lungs [3]. One of the key roles of pericytes is to maintain endothelial integrity. Moreover, their loss or detachment promotes endothelial cell sprouting and intussusception. Two recent single cells analyses demonstrated that endothelial cells have a very weak expression of angiotensin-converting enzyme 2 (ACE2), while pericytes are among the cells that have the highest expression of ACE2 $[4,5]$. More than a direct viral effect on endothelial cells or perivascular inflammation, the profound decrease in pericytes and observed apoptosis strongly suggest that the alteration of pericytes by a direct effect of SARS-CoV-2 could be the initial trigger of the micro-vasculopathy. These findings are of critical importance as they could explain the systemic manifestations reported with COVID-19 infection and foster new

\section{Springer}



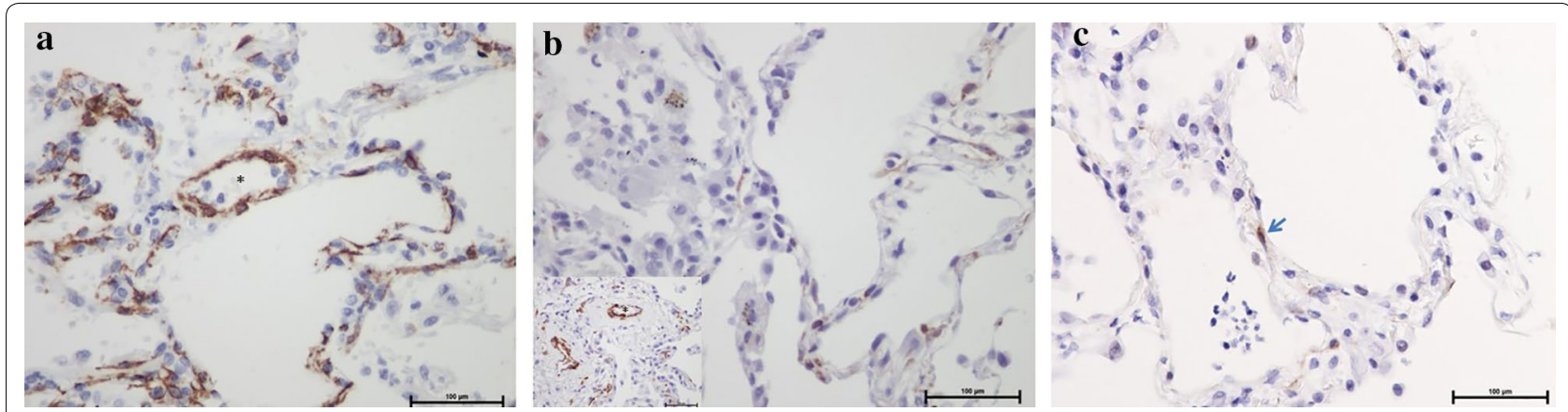

Fig. 1 Pericyte loss in the lung of COVID-infected patient. Pericytes, highlighted by a SMA immunostaining ( $\times$ 400), were dramatically decreased in alveolar capillaries in COVID + lung (b), while they were abundant in normal parenchyma (a) (asterisk shows venules lumen). Pericytes seemed preserved in venular walls in COVID + (B insert). Cleaved caspase 3 staining revealed apoptosis of a pericyte in inter-alveolar septum of COVID + lung (c)

\section{therapeutic approaches, such as prostacyclin to target the} micro-vasculopathy.

\section{Electronic supplementary material}

The online version of this article (https://doi.org/10.1007/s00134-020-06147-7) contains supplementary material, which is available to authorized users.

\section{Author details}

1 'Department of Pathology, Université Côte D'Azur. CHU Nice, Nice, France. ${ }^{2}$ Department of Dermatology, Université Côte D'Azur. CHU Nice, Nice, France. ${ }^{3}$ Medical Intensive Care Unit, Université Côte D'Azur. UPR 01, UR2CA, CHU Nice, Nice, France. ${ }^{4}$ Université Côte D'Azur. INSERM. U1065, C3M Nice, France.

\section{Author contributions}

Drs Leccia, Hubiche and Passeron had full access to all the data in the study and take responsibility for the integrity of the data and the accuracy of the data analysis. Concept and design: Leccia, Hubiche, Burel-Vandebos, Passeron. Acquisition, analysis, or interpretation of data: All authors. Drafting of the manuscript: Leccia, Hubiche, Passeron. Critical revision of the manuscript for important intellectual content: Dellamonica, Burel-Vandenbos, Passeron. Statistical analysis: NA. Administrative, technical, or material support: BurelVandenbos, Passeron. Supervision: Dellamonica, Burel-Vandenbos, Passeron.

\section{Funding}

Centre Hospitalier Universitaire de Nice, France. The funders/sponsors had no role in the design and conduct of the study; collection, management, analysis, and interpretation of the data; preparation, review, or approval of the manuscript; and decision to submit the manuscript for publication.

\section{Compliance with ethical standards}

\section{Conflicts of interest}

The authors declare no conflict of interest.

\section{Publisher's Note}

Springer Nature remains neutral with regard to jurisdictional claims in published maps and institutional affiliations.
Accepted: 28 May 2020

Published online: 12 June 2020

\section{References}

1. Helms J, Kremer S, Merdji H, Clere-Jehl R, Schenck M, Kummerlen C, Collange O, Boulay C, Fafi-Kremer S, Ohana M, Anheim M, Meziani F (2020) Neurologic features in severe SARS-CoV-2 infection. N Engl J Med 382(23):2268-2270

2. Lang M, Som A, Mendoza DP, Flores EJ, Reid N, Carey D, Li MD, Witkin A, Rodriguez-Lopez JM, Shepard JO, Little BP (2020) Lancet Infect Dis S1473-3099(20)30367-4

3. Ackermann M, Verleden SE, Kuehnel M, Haverich A, Welte T, Laenger F, Vanstapel A, Werlein C, Stark H, Tzankov A, Li WW, Li VW, Mentzer SJ, Jonigk D (2020) Pulmonary vascular endothelialitis, thrombosis, and angiogenesis in COVID-19. N Engl J Med. https://doi.org/10.1056/NEJMo a2015432

4. Chen L, Li X, Chen M, Feng Y, Xiong C (2020) The ACE2 expression in human heart indicates new potential mechanism of heart injury among patients infected with SARS-CoV-2. Cardiovasc Res 116(6):1097-1100

5. Ziegler CGK, Allon SJ, Nyquist SK, Mbano IM, Miao VN, Tzouanas CN, Cao Y, Yousif AS, Bals J, Hauser BM, Feldman J, Muus C, Wadsworth MH, Kazer SW, Hughes TK, Doran B, Gatter GJ, Vukovic M, Taliaferro F, Mead BE, Guo Z, Wang JP, Gras D, Plaisant M, Ansari M, Angelidis I, Adler H, Sucre JMS, Taylor CJ, Lin B, Waghray A, Mitsialis V, Dwyer DF, Buchheit KM, Boyce JA, Barrett NA, Laidlaw TM, Carroll SL, Colonna L, Tkachev V, Peterson CW, Yu A, Zheng HB, Gideon HP, Winchell CG, Lin PL, Bingle CD, Snapper SB, Kropski JA, Theis FJ, Schiller HB, Zaragosi L-E, Barbry P, Leslie A, Kiem H-P, Flynn JL, Fortune SM, Berger B, Finberg RW, Kean LS, Garber M, Schmidt AG, Lingwood D, Shalek AK, Ordovas-Montanes J (2020) SARS-CoV-2 receptor ACE2 is an interferon-stimulated gene in human airway epithelial cells and is detected in specific cell subsets across tissues. Cell 181(5):1016-1035.e19 